\title{
PENGARUH PENERAPAN STRATEGI PRACTICE REHEARSAL PAIRS TERHADAP HASIL BELAJAR MENGANYAM VAS BUNGA SISWA KELAS VIII SMP NEGERI 2 SUNGGGAL
}

\author{
Halida Hanim dan Aulia Syafitri*) \\ Surel: halidahanimp@gmail.com
}

\begin{abstract}
The This study aimed to determine the differences in student learning out comes using strategi practice rehearsall pairs learning model with convention learning models in the competency of plaiting vase in grade VIII of SMP Negeri 2 Sunggal. The samples were two classes randomly selected. The first class in strtegi practice rehearsal pairs teaching used and second classs in convensional learning model. The instrument of data collection was the observation sheet. Data were analyzed using t-tes analysis technique. Based on the calculations, the value of $t=5,845>t 1,669$ at the $5 \%$ significant level, the hypothesis which states that there was a significant difference in learning outcomes between the results of learning in plaiting vase using learning model strategi practice rehearsal pairs with conventional learning model on students grade VIII.
\end{abstract}

Kata Kunci: Menganyam Vas Bunga, Strategi Practice Rehearsal Pairs

PENDAHULUAN

$\begin{array}{lcr}\text { endidikan } & \text { Proses } & \text { belajar } \\ \text { mengajar } & \text { di } & \text { sekolah } \\ \text { merupakan } & \text { suatu } & \text { proses }\end{array}$ interaksi antara guru dan siswa beserta komponen-komponen yang ada di dalamnya, antara lain tujuan materi pelajaran, sarana dan prasarana, situasi dan kondisi belajar, media pembelajaran, lingkungan belajar, metode dan strategi pembelajaran, serta evaluasi. Semua komponen pembelajaran tersebut sangat mempengaruhi keberhasilan proses belajar.

Strategi pembelajaran dipandang berperan dalam keberhasilan proses belajar mengajar. Dengan melihat kondisi kebutuhan siswa, guru diharapkan mampu menciptakan strategi yang menarik dan bervariasi, yang membuat suasana belajar menjadi menyenangkan dan tidak membosankan.

Sekolah Menengah Pertama (SMP) merupakan jenjang pendidikan formal yang bertujuan meningkatkan kecerdasan, pengetahuan, kepribadian, akhlak mulia, serta keterampilan untuk hidup mandiri dan menyiapkan siswa menuju ke jenjang pendidikan lebih lanjut. Sekolah Menengah Pertama (SMP) memberikan bekal kemampuan kognitif, afektif, dan psikomotorik untuk mempersiapkan peserta didik menjadi lebih berkompetensi. Tetapi, tidak semua lulusan SMP dapat melanjutkan ke pendidikan yang lebih tinggi ,sebagian di antaranya harus

\footnotetext{
* ) Dra. Halida Hanim, M.Pd: Dosen Jurusan PKK FT UNIMED Aulia Syafitri: Mahasiswa Jurusan PKK FT UNIMED 
memasuki dunia kerja. Oleh karena itu kurikulum di tingkat SMP memuat mata pelajaran keterampilan. Mata pelajaran ini perlu diberikan kepada peserta didik ditingkat SMP, sehingga jika mereka tidak melanjutkan ke pendidikan yang lebih tinggi mereka telah mempunyai bekal keterampilan yang nantinya akan dapat berguna untuk kehidupan mendatang. Mata pelajaran keterampilan mempunyai fungsi mengembangkan pengetahuan, keterampilan, kreatifitas, dan sikap dalam berkarya. Pembelajaran keterampilan berorientasi pada pembuatan hasil karya yang ditunjang oleh pengetahuan, sikap dan keterampilan.

Mata pelajaran keterampilan merupakan mata pelajaran muatan lokal yang wajib ditempuh di SMP Negeri 2 Sunggal. Membuat kerajinan anyaman berupa vas bunga merupakan salah satu kompetensi yang ada pada mata pelajaran keterampilan. Kerajinan anyaman diberikan dengan tujuan agar siswa memiliki kecakapan dan keterampilan dalam membuat benda dengan menggunakan teknik anyam sesuai kreativitas masing-masing, sehingga menghasilkan produk fungsional yang berkualitas. Dalam pembuatan vas bunga ini menggunakan bahan limbah kertas koran yang mudah didapat dil ingkungan sekitar tempat tinggal siswa dengan teknik anyaman melingkar.
Berdasarkan hasil wawancara penulis dengan guru mata pelajaran keterampilan di SMP Negeri 2 Sunggal (Misnawati, 2016) bahwa selama ini kegiatan pembelajaran menggunakan Teacher-Centered yaitu guru menjelaskan konsep-konsep yang ada pada buku ajar.

Keberhasilan proses belajar siswa dalam mata pelajaran keterampilan tidak terlepas dari komponen-komponen pembelajaran yang berperan di dalamnya, antara lain strategi pembelajaran. Strategi pembelajaran merupakan salah satu komponen yang dianggap berpengaruh terhadap keberhasilan proses belajar. Guru diharapkan mampu menciptakan strategi pembelajaran yang menarik. Suasana pembelajaran yang menarik dapat menciptakan proses belajar mengajar yang baik sehingga tujuan pembelajaran dapat tercapai. Untuk itu tugas guru adalah memilih strategi pembelajaran yang tepat untuk menciptakan proses belajar. Hal ini tentunya tidak menutup kemungkinan strategi pembelajaran PracticeRehearsal Pairs untuk diterapkan pada siswa.

Strategi Practice-Rehearsal Pairs adalah strategi yang dipakai untuk menpraktekkan suatu keterampilan atau prosedur dengan teman belajar. Menurut Zaini (2009) Strategi Practice-Rehearsal Pairsini merupakan alternatif yang dapat diterapkan kepada siswa untuk 
pembelajaran yang bersifat psikomotorik. Strategi ini digunakan untuk memperoleh keberhasilan dalam mempraktekkan suatu keterampilan dengan teman belajar yang melibatkan mental dan fisik peserta didik dengan harapan suasana pembelajaran lebih aktif dan menyenangkan sehingga dapat memaksimalkan hasil belajar siswa.

Berdasarkan uraian di atas, penulis tertarik untuk menjadikan permasalahan tersebut sebagai topik yang diteliti dengan judul "Pengaruh Penerapan Strategi Pembelajaran Practice-Rehearsal Pairs Terhadap Hasil Bela jar Menganyam Vas Bunga Kelas VIII SMP Negeri 2 Sunggal”.

\section{METODE PENELITIAN}

Desain penelitian yang digunakan dalam penelitian ini adalah Posttest Only Control Group Design. Sementara metode penelitian yang digunakan adalah metode eksperimen semu (Quasi experiment) yaitu untuk memperoleh informasi yang merupakan perkiraan bagi informasi yang dapat diperoleh dengan eksperimen yang sebenarnya dalam keadaan yang tidak memungkinkan untuk mengontrol dan/atau memanipulasikan semua variabel yang relevan.

$$
\text { Penelitian ini akan }
$$

dilaksanakan di SMP Negeri 2 Sunggal yang beralamat Jln. MedanBinjai, km.12,5 Kecamatan Sunggal. Waktu pelaksanaan penelitian pada semester ganjil tahun 2016/2017 di kelas VIII SMP Negeri 2 Sunggal.

Populasi dalam penelitian ini yaitu siswa kelas VIII yang berjumlah 222 siswa terdiri dari 6 kelas. Teknik pengambilan sampel pada penelitian ini adalah Purposive Sampling, yang dipilih adalah siswa Kelas $\mathrm{VIII}_{5}$ berjumlah 37 siswa dan Kelas $\mathrm{VIII}_{6}$ yang berjumlah 36 siswa.

Instrumen yang digunakan untuk menjaring data hasil belajar menganyam adalah lembar pengamatan yang telah diuji validitas dan reliabilitasnya. Uji hipotesis penelitian dilakukan dengan menggunakan uji " $\mathrm{t}$ ".

\section{HASIL PENELITIAN}

Tabel. 1 Distribusi Frekuensi Hasil Belajar Menganyam Vas Bunga Pada Kelas Eksperimen

\begin{tabular}{|c|c|c|c|}
\hline Kelas & $\begin{array}{c}\text { Interval } \\
\text { Nilai }\end{array}$ & $\begin{array}{c}\text { Frek. } \\
\text { Absolut }\end{array}$ & $\begin{array}{c}\text { Frek. } \\
\text { Relatif } \\
(\%)\end{array}$ \\
\hline 1. & $74-77$ & 3 & $8.33 \%$ \\
\hline 2. & $78-81$ & 8 & $22.22 \%$ \\
\hline 3. & $82-85$ & 4 & $11.11 \%$ \\
\hline 4. & $86-89$ & 8 & $22.22 \%$ \\
\hline 5. & $90-93$ & 3 & $8.33 \%$ \\
\hline 6 & $94-97$ & 6 & $16.66 \%$ \\
\hline 7 & $98-101$ & 4 & $11.11 \%$ \\
\hline \multicolumn{2}{|c|}{ Jumlah } & 36 & $100 \%$ \\
\hline
\end{tabular}

Berdasarkan data hasil belajar untuk kelas kontrol yang diperoleh dari 37 sampel diketahui nilai tertinggi 100 dan nilai terendah 25 dengan rata-rata skor $(M)=77,84$ dan standart deviasi $(\mathrm{SD}) \quad=5,78$. Distribusi frekuensi hasil belajar 
menganyam vas bunga untuk kelas kontrol dapat dilihat pada tabel berikut.

Tabel. 2 Distribusi Frekuensi Hasil Belajar Menganyam Vas Bunga pada Kelas Kontrol

\begin{tabular}{|c|c|c|c|}
\hline Kelas & $\begin{array}{c}\text { Interval } \\
\text { Nilai }\end{array}$ & $\begin{array}{c}\text { Frek. } \\
\text { Absolut }\end{array}$ & $\begin{array}{c}\text { Frek. } \\
\text { Relatif } \\
(\%)\end{array}$ \\
\hline 1. & $70-74$ & 7 & $18.91 \%$ \\
\hline 2. & $75-79$ & 20 & $54.05 \%$ \\
\hline 3. & $80-83$ & 4 & $10.81 \%$ \\
\hline 4. & $84-88$ & 3 & $8.10 \%$ \\
\hline 5. & $89-93$ & 2 & $5.40 \%$ \\
\hline 6. & $94-98$ & 1 & $2.70 \%$ \\
\hline \multicolumn{2}{|c|}{ Jumlah } & 37 & $100 \%$ \\
\hline
\end{tabular}

Tingkat kecenderungan hasil belajar menganyam vas bunga pada kelas eksperimen disesuaikan dengan kriteria ketuntasan minimum (KKM) SMP Negeri 2 Sunggal. Data selengkapnya disajikan pada table berikut.

Tabel 3. Tingkat Kecenderungan Hasil Belajar Menganyam Vas Bunga Kelas Eksperimen

\begin{tabular}{|c|c|c|c|}
\hline Keterangan & $\mathbf{f}_{\text {absolut }}$ & $\mathbf{f}_{\text {relatif }}$ & Kategori \\
\hline$<75$ & 2 & $5,55 \%$ & Kurang \\
\hline $75-84$ & 11 & $30,55 \%$ & Cukup \\
\hline $85-90$ & 13 & $36,11 \%$ & Baik \\
\hline $91-100$ & 10 & $27,77 \%$ & $\begin{array}{c}\text { Sangat } \\
\text { Baik }\end{array}$ \\
\hline Jumlah & 36 & $100 \%$ & \\
\hline
\end{tabular}

Dari tabel di atas dapat dilihat bahwa jumlah responden yang termasuk kategori sangat baik dengan jumlah 10 siswa $(27,77 \%)$, kategori baik dengan jumlah 13 siswa $(36,11 \%)$, kategori cukup dengan jumlah 11 siswa $(30,55 \%)$ dan kategori kurang dengan jumlah 2 siswa (5,55\%). Dengan demikian dapat disimpulkan bahwa hasil belajar menganyam vas bunga di kelas eksperimen tergolong dalam kategori baik $(36,11 \%)$.

\section{Tabel 4. Tingkat Kecenderungan Hasil} Belajar Menganyam Vas Bunga

\begin{tabular}{|c|c|c|c|}
\hline Keterangan & fabsolut & frelatif & Kategori \\
\hline$<75$ & 7 & $18.91 \%$ & Kurang \\
\hline $75-84$ & 26 & $70.27 \%$ & Cukup \\
\hline $85-90$ & 2 & $5.40 \%$ & Baik \\
\hline $91-100$ & 2 & $5.40 \%$ & $\begin{array}{c}\text { Sangat } \\
\text { Baik }\end{array}$ \\
\hline Jumlah & 37 & $100 \%$ & \\
\hline
\end{tabular}

Dari tabel di atas dapat dilihat bahwa jumlah responden yang termasuk kategori sangat baik berjmlah 2 siswa $(5,40 \%)$, kategori baik dengan jumlah 2 siswa $(5,40 \%)$, kategori cukup dengan jumlah 26 siswa $(70,27 \%)$ dan kategori kurang dengan jumlah 7 siswa $(18,91 \%)$. Dengan demikian dapat disimpulkan bahwa hasil belajar menganyam vas bunga di kelas kontrol tergolong dalam kategori cukup yaitu 26 siswa $(70,27 \%)$

Sebelum dilakukan pengujian hiotesis, maka dilakukan uji normalitas dan homogenitas. Ternyata sebaran data berdistribusi normal dan mempunyai variance yang sama (homogegen). Berdasarkan hasil perhitungan diperoleh $t_{\text {hitung }}=5,8451, t_{\text {tabel }}=1,6686$ pada taraf signifikan $5 \%$ maka 
$t_{\text {hitung }}>t_{\text {tabel }} \quad=5,8451>\quad 1,6686$.

Dengan demikian dinyatakan bahwa "Terdapat pengaruh strategi pembelajaran practice-rehearsal pairs terhadap hasil belajar menganyam vas bunga pada siswa kelas VIII SMP Negeri 2 Sunggal”.

\section{PEMBAHASAN} PENELITIAN

Hasil perhitungan yang diperolah dari data hasil belajar menganyam vas bunga pada kelas eksperimen memperoleh nilai ratarata 87 dengan nilai tertinggi 100 dan standart deviasi 7,43 sedangkan pada kelas kontrol memperoleh nilai ratarata 77,94 dengan nilai tertinggi 98 dan standar deviasi 5,78. Berdasarkan hasil uji kecenderungan diketahui hasil belajar menganyam vas bunga pada kelas eksperimen dikategorikan cenderung baik . Pada kelas kontrol tergolong dalam kategori cenderung cukup

Dari hasil perhitungan $t_{\text {hitung }}>t_{\text {tabel }}$ atau $5,8451>1,6686$ sehingga dapat dikatakan bahwa terdapat pengaruh strategi pembelajaran practice-rehearsal pairs terhadap hasil belajar menganyam vas bunga pada siswa kelas VIII SMP Negeri 2 Sunggal.

Adanya pengaruh hasil belajar pada kelas eksperimen disebabkan oleh adanya perlakuan, yaitu menggunakan strategi pembelajaran practice-rehearsal pairs . Strategi pembelajaran ini menempatkan siswa belajar dengan teman belajar dan memungkinkan keduanya untuk mengkomunikasikan prosedur dan langkah kerja suatu keterampilan sehingga tercipta situasi belajar yang aktif, menyenangkan dan saling bekerjasama. Disamping itu practis rehearsal pairs ini bertujuan untuk meyakinkan masing-masing pasangan dapat melakukan keterampilan dengan benar, karena materi yang besifat psikomotorik adalah materi yang baik untuk diajarkan dengan strategi ini.

\section{SIMPULAN}

1. Hasil belajar menganyam vas bunga di kelas eksperimen berada pada kategori cenderung baik.

2. Hasil belajar menganyam vas bunga di kelas kontrol berada pada kategori cenderung cukup.

3. Terdapat pengaruh strategi pembelajaran practice-rehearsal pairs terhadap hasil belajar menganyam vas bunga pada siswa kelas VIII SM Negeri 2 \Sunggal, harga $\quad t_{\text {hitung }}>t_{\text {tabel }}$ atau $5,8451>1,6686$

\section{DAFTAR PUSTAKA}

Chairani. (2013). Kerajinan Anyam. Medan. Fakultas Bahasa dan Senitas Negeri Medan.

Departermen Pendidikan dan Kebudayaan. (2006). Pendidikan Keterampilan. Jakarta. Direktorat Jenderal 


$\begin{array}{ll}\text { Manajemen } & \text { Pendidikan } \\ \text { Dasar dan } & \text { Menengah. } \\ \text { Departemen } & \text { Pendidikan } \\ \text { Nasional } & \end{array}$

Freddimarta's Blog. (2015). Kelebihan dan Kekurangan Strategi Practice-Rehearsal Pairs. (Online).

Tersedia:http://freddimarta.bl ogspot.co.id/2015/02/perbed aanstrategi.htm

Istarani. (2012). 58 Model Pembelajaran Inovatif. Medan: Media Persada.

Sanjaya, Wina (2006). Strategi Pembelajaran. Jakarta. Kencana.

Silberman, Mel. (2010). 101 Cara Pelatihan dan Pembelajaran Aktif. Translate by Dani Dharyani. 2010. Jakarta. Indeks.

Sugiyono. (2012). Metode Penelitian Kuantitatif Kualitatif Dan R\&D. Bandung: Alfabeta.

Zaini, Hisyam. (2008). Strategi Pembelajaran Aktif. Yogyakarta. Pustaka Insan Mandiri. 